\title{
Obituaries / Nécrologie
}

\section{Philip E. Anslow, Forester 1923-1999}

On November 12, 1999, the forestry community lost one of its most dedicated foresters, Phil Anslow. Born in the Ottawa Valley, he grew up in what was one of Canada's most important forestry regions, with its legendary white pine. In later years, Phil dedicated considerable time and effort to the re-establishment of this species, in his words "using the best available planting stock on the right sites, properly prepared."

Prior to the beginning of Phil's forestry career, he served in the Canadian Navy during the second world war aboard the Sackville, Chambly and the Puncher as a leading telegraphist. His life experiences on the rough, rolling seas of the north Atlantic provided many of the famous quotes and sayings used years later when making his point to those around him.

After graduating in 1950 from the Faculty of Forestry, University of Toronto, with a Bachelor of Science in Forestry, Phil spent his first two years with the Forest Resources Inventory Unit in Toronto. In 1952 he became management forester on the Petawawa and Kiosk Management Units in the Pembroke District of the Ontario Department of Lands and Forests. Four years later, Phil was promoted to Timber Management Supervisor in Cochrane.

Phil remained in Cochrane for nine years before transferring to the old Kemptville District as Timber Supervisor. With reorganization and the establishment of the Ontario Ministry of Natural Resources in 1973 he became Regional Forester for the Eastern Region, a position he held until retirement in 1988. Following retirement from the Ministry, he remained active as a business consultant with the Federal Business Development Bank.

During his tenure in eastern Ontario, the foundation was laid for a significant forestry program on Crown, municipal and private lands. He was an innovator of private land forestry and a pioneer in intensive forest management. The G. Howard Ferguson Forest Station, in addition to producing seedlings, became a tree improvement and forest interpretive centre. Phil was instrumental in the establishment of such things as the Technical Forestry Course at Sir Sanford Flemming College, the Hybrid Poplar and New Forests Tech-

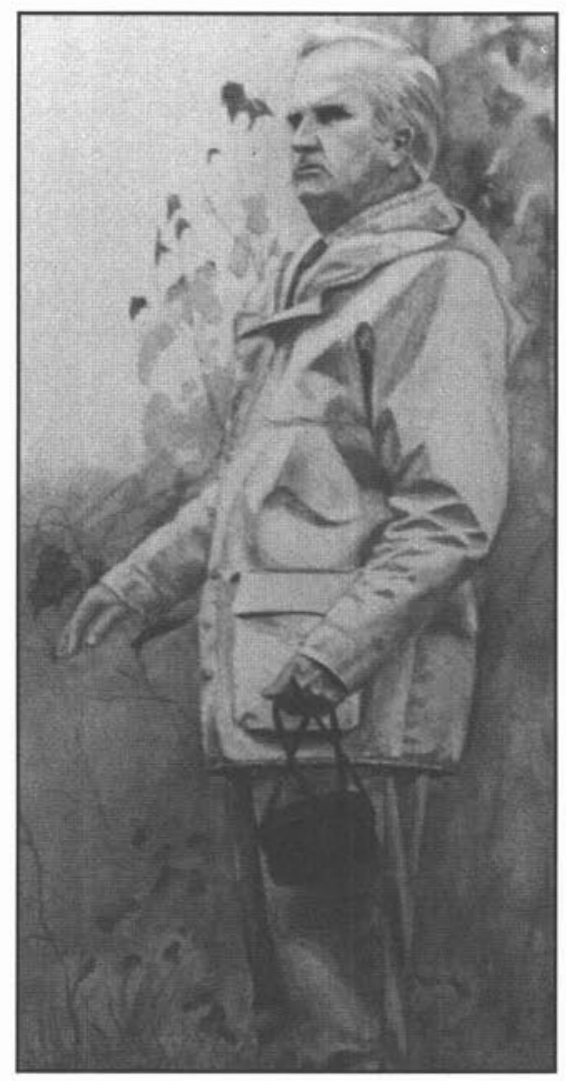

Philip E. Anslow

nology Development Unit, and the Domtar Woodshed program - all provincial firsts that often gained international attention.

The series of workshops, field tours and seminars established under his leadership shared knowledge and motivated others to do their best. The annual Christmas Forestry Seminar started by him has continued for over 20 years. Phil helped broaden the horizon for many people, recognizing their talent, and encouraging them to use it and take on challenges.

Bringing together the scientist, practitioner, logger, landowner, bureaucrat and politician he accomplished much, to the betterment of the forests and the communities of eastern Ontario.

To quote the opening from one of his famous expressions "there is no way on God's green earth"... that the forests of our region would be as rich as they are today without the dedicated effort of Phil Anslow.

Brian A. Barkley, R.P.F. General Manager Eastern Ontario Model Forest

\section{Robert (Bob) Wood, RPF, 1931-2000}

The Canadian forest community has lost one of its most prominent and respected members. Robert (Bob) S. Wood, R.P.F., passed away on January 15,2000 after a lengthy illness.

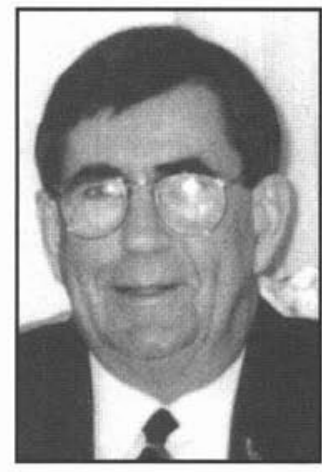

Born in Ladysmith in 1931 into a family of Scottish pioneers, Bob received his earlier education in that Vancouver Island centre and then moved to Vancouver to pursue his forestry studies at the University of British Columbia. He graduated from that institution with his Bachelor of Science in Forestry (Honours) in 1954, receiving the H.R. MacMillan Prize as top graduate. He subsequently took simultaneous Master of Science (Forestry) degrees from Syracuse University and the State University of New York, completing them in 1956.

A distinguished 40-year career followed. From Operations Forester at the UBC Research Forest, he moved to Weldwood of Canada where by 1965 he was Chief Forester for that company. A position as Vice President, Forestry and Logging with the Council of Forest Industries of BC followed until he opened a private consultancy with partner Bill Sterling. In 1974 he became Vice President of Reid Collins and Associates in charge of forest policy and feasibility analyses.

In 1975 Bob accepted an invitation to serve as Senior Special Forestry Advisor to the BC Ministry of Lands and Forests. This led to his appointment as Chair of the Forest Policy Advisory Committee which was charged with overseeing the preparation of the Ministry of Forests Act, the Forest Act and the Range Act. These items of legislation are major milestones in the Province's forest policy history and were adopted by the BC legislature in 1978 . Having completed his responsibilities in this historic work, Bob returned to private consulting where his work in forestry and trade matters took him worldwide. He was a lead consultant for Canada in the Canada/US softwood 
lumber trade disputes in the 1980 s and early 1990 s.

Bob Wood made a profound contribution to forestry and to his profession in his home province and country. Over the years, many young foresters were the fortunate recipients of his help as he generously shared his knowledge and experience with them. As a measure of the high regard held for him by his peers, Bob, in 1980, was presented with the Distinguished Forester Award of the Association of BC Professional Foresters.

The condolences of the entire forestry community go to Bob's family.

\section{David John Presslee 1952-2000}

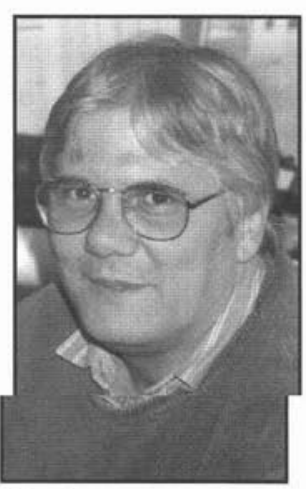

The forestry communities in Alberta and British Columbia were saddened by the death on January 29, 2000 of David Presslee, Forestry Manager for Weidulwoud ${ }^{3}$ or ${ }^{5}$ Canada Limited (Hinton Division).

David was a registered professional forester in both British Columbia and Alberta and was highly regarded for his efforts to advance the practice of ecologically based forest management. His career included service as Silviculture Manager for Northwood in Prince George, playing his part in establishing what he liked to refer to as the "world's largest plantation" - the Bowron Valley - and continued at Hinton as he led the charge to integrate harvest and silviculture planning. At the time of his death, he was spearheading research and development of an intensive management program at Hinton. He also played a lead role in many forestry-based programs of Foothills Model Forest.

His life-long commitment to learning included earning a Forest Technology diploma at the Northern Alberta Institute of Technology (1977), his RPF through the pupil program in British Columbia (1983), his RPF in Alberta (1994) and a General Studies (Arts and Science) degree from Athabasca University in 1996.

In addition to forestry, David had a passion for music. A former professional

\section{Section News / Nouvelles des Sections}

\section{VANCOUVER ISLAND} Guest Speaker

The Vancouver Island Section was pleased to have Bill Cafferata, Chief Forester with MacMillan Bloedel (now Weyerhaeuser Company Canada Ltd.) as the guest speaker for our dinner meeting on the evening of January $20^{\text {th }}$.

Some interesting observations from Bill included:

Weyerhaeuser is celebrating their 100 th anniversary in business. Twentyfive years ago, they were the same size as MacMillan Bloedel and today they are third largest forest products company in North America. Their annual sales are equal to that of the entire $\mathrm{BC}$ forest industry. The merger with MB was the largest in Weyerhaeuser's history.

Weyerhaeuser have a reputation for growing Douglas-fir with a 45-yr rotation on high sites and they make a good protit on second growth because they know how to dry it and market it. They are very community conscious and aren't afraid to commit resources to communityrelated issues and concerns.

The coastal operations of MB Ltd. were a good mix with Weyerhaeuser's other Canadian operations in Kamloops, BC, Prince Albert, Sask. and Dryden, Ont. Their AAC on the BC coast is 1 million cubic meters on private land and 4.5 to 4.7 million cubic metres on Crown land. MB's variable retention harvesting left $18 \%$ of volume on-site, while Weyerhaeuser's left $14 \%$. The company employs 900 people in their Tacoma, Washington research facility.

Weyerhaeuser found out after the merger that MB was moving wood to Japan cheaper than they could. The company uses 13 helicopters in their forestry operations. The nomenclature was

musician with the band "Missouri," he was a member of Alberta's all-forester bluegrass band "Stumped."

Dave leaves behind his wife Roseann, and children Kerri and William James. vastly different between the two companies so they learned each other's vernacular through a book called "alphabet soup."

Bill spoke about the challenges and changes that were faced as the two organizations were brought together through the recent purchase of MacMillan Bloedel by Weyerhaeuser. One of differences was the additional emphasis that Weyerhaeuser placed on safety. Bill stressed that MB was very conscious of safety but he felt that Weyerhaeuser placed an even greater emphasis on the challenges of keeping the workplace safe. As an example, Bill said that every meeting began with a description of where the exits were and where first aid kits were located.

Bill also described the team approach taken by Weyerhaeuser. Everyone works in teams and each person is very famil1är with team objectives and their part in meeting those objectives. The various "businesses" that Weyerhaeuser is organized into were also described. An example was a pulp and paper and sawmill complex that, at first appearance, would seem to be a unit unto itself. In fact Weyerhaeuser has complexes such as this reporting through several business lines that keep activities such as woodlands, sawmills, pulp mills and paper mills each as part of separate business units.

Bill also talked about some of the more "public" issues related to the purchase, such as the MacMillan Bloedel decision to eliminate clearcutting from their coastal operations and adopt a "variable retention" system. Weyerhaeuser was under considerable pressure to agree to continue to follow this approach but they did not immediately agree to do so. They said they would look at it. The company subsequently agreed to follow the approach adopted by MB but not before they had looked at closely and understood what it meant and what the impacts would be.

Bill was very generous with his time and fielded many questions about MB experiences with issues such as Clayoquot Sound, the Scientific Panel and First Nations issues. It was quite apparent that MB (and Bill Cafferata) has been in 